Review Articles

\title{
Infection Control: Methicillin Resistant Staphylococcus Aureus
}

\author{
${ }^{1,3}$ Cheryl Ann Alexander and ${ }^{2}$ Lidong Wang \\ ${ }^{I}$ Department of Nursing, University of Phoenix, USA \\ ${ }^{2}$ Department of Engineering Technology, Mississippi Valley State University, USA \\ ${ }^{3}$ Technology and Healthcare Solutions, Inc., USA
}

Article history

Received: 27-03-2015

Revised: $16-05-2015$

Accepted: 02-09-2015

Corresponding Author:

Lidong Wang

Department of Engineering

Technology, Mississippi Valley

State University, USA

E-mail: lwang22@students.tntech.edu

\begin{abstract}
Health care personnel come into contact with Methicillin Resistant Staphylococcus aureus (MRSA) on a daily basis. Emergency practitioners must become aware of the trend toward community and health care acquired infections and how to treat and prevent them. Medication treatment is specific to each infection. Disease prevention is mandatory to keep the number of cases decreasing. In this study, a survey of literature has been conducted on the evolution of health care acquired infection based on level of evidence. Early identification and isolation for MRSA at the point of patient entry can prevent MRSA spread and Health Care Associated Infections (HAIs).
\end{abstract}

Keywords: Infection Control, Health Assessment, Medication Management, Disease Prevention Emergency Room, Intensive Care, Nursing

\section{Introduction}

Health care workers and people in the general community alike are both at risk for being exposed to one of the most common virulent strains of bacterial infections seen in decades. This bacterial infection, known as MRSA, has been seen in widespread outbreaks from across the country. Most patients infected with MRSA are seen in the Emergency Room (ER) as the first point of contact for the infection. The infection causes large, painful abscesses that do not usually subside without treatment or incision and drainage (I\&D). Many ER staff are not sufficiently educated to identify and isolate MRSA upon arrival to triage (Carman et al., 2011). A significant task for ER leaders and nurse practitioners is finding a solution for monitoring the number of MRSA cases and giving the appropriate treatment while sufficiently isolating the patient from others more susceptible to the infection. Out of the many skin and soft tissue infections, MRSA has increased from $59 \%$ in 2004 to $79 \%$ in 2009 (Shapiro et al., 2009). Most cases present as a "spider bite". Costly complications such as necrotizing fasciitis, sepsis and MRSA pneumonia are capable of serious consequences. Although the CDC reports a decline in MRSA infections, recent statistics still report nearly 50\% infection rate (CDC, 2011). The cost of contact isolation for one patient with an active MRSA infection is around $\$ 8,000$ per year (Spence et al., 2012). At least onethird of patients isolated with MRSA will go on to develop an active infection. This data and that many cases occur within $72 \mathrm{~h}$ of admission, reinforce the fact that the emergency room should be doing routine screening of patients and that this screening plays an important role in the total number of active MRSA infections (Guleri et al., 2011). Nurse practitioners working in the emergency room are in a primary position to effect change in policy and treatment; implementing evidence-based nursing practice as guidelines for treatment and isolation.

Cases of MRSA have declined in previous years among adults. Recent statistics from US agencies reflect a $31 \%$ reduction in invasive MRSA infections over seven years where healthcare-associated MRSA bacteremia has been a reportable disease. The drop most recently has been even steeper at $69 \%$. The total number of patients with MRSA bacteremia fell from 2935 in2008/2009 to 924 in 2011/2012. Similarly, in most European Union countries, the proportion of MRSA among invasive $S$. aureus infections is stagnating, or even declining greatly (Meyer et al., 2014).

According to Kuehnert et al. (2006), statistical data for MRSA indicates a decline in infection rate but an increase in prevalence among six to 11-year- 
olds. While the prevalence rates differ demographically, there is little variance in the rate of complications. Most people in the community are already colonized with MRSA but do not have active infections. Prevention and education about the spread of infectious skin infections and isolation of patients currently infected with MRSA skin infections on point of contact will help decrease the number of active cases. Nurse practitioners working in the emergency room should make priority decisions about actively isolating MRSA patients on point of care and educate patients about preventing further outbreaks such as instructing about hand-washing, hygiene and signs and symptoms of further infection and sources of transmission.

It is a well-known fact that within Europe, resistance rates in MRSA are subject to wide variation, with high rates in the south and comparatively low rates in the Netherlands and Scandinavia. MRSA strains are still common multiresistantpathogens, even though multiresistant Gram negative pathogens are on the increase. In the US, for example, the prevalence of MRSA within individual states ranges from 0/1000 patients in South Dakota to $110.8 / 1000$ patients in Texas and it generally seems lower in the northwest than in the southeast. The Hospital Infection Surveillance System (KISS) has existed since 1997 and includes data about some selected nosocomial infections in various risk areas, such as intensive care units or surgical wards (Meyer et al., 2014). Participationin the scheme is voluntary and individual participants'data are strictly confidential. The fact that participation is voluntary explains the fact that over the years, the numbers of intensive care wards and surgical wards have varied (Meyer et al., 2014). This study examines MRSA practice issues for the emergency nurse practitioner and acute care practitioner.

\section{Identification of Practice Issue and Infection Control}

At Methodist University in Memphis, Tennessee, patients identified with skin and soft tissue infections classified as MRSA are currently not isolated from other patients or put on contact precautions upon triage or initial culture identification. There are no protocols in the ER to determine who goes on contact precautions and who does not. Based on presenting signs and symptoms, patients who are infected with MRSA receive neither a rapid nasal nor wound swabs, nor a different treatment plan than any other patient with a soft skin infection. No follow-up treatment is routinely done for patients admitted to the ER with MRSA, even when patient compliance is questionable.
This lack of follow-up and protocols must be addressed. The PICO question is, "Should best practice for emergency room patients include early identification and isolation for MRSA?"PICO identifies the patient problem. It stands for Population (P), intervention (I), Comparison (C) and outcome(s) (o). Table 1 shows the colonization by health care contact within the past three months and antibiotic use in the previous month.

\section{Search Strategy}

The search was performed using the University of Phoenix's Biomedical Library and the University of Phoenix E-campus Library. Databases searched included CINAHL, EBSCO Database, Google Scholar, OVID Database, PubMed Database and Gale Database. The National Clearinghouse Guidelines and Agency for Healthcare Research and Quality were also searched. Keywords used for the searches included: Methicillin-Resistant Staphylococcus aureus, isolation procedures, MRSA and isolation, emergency room MRSA isolation procedures and MRSA protocols. All studies were fewer than five years old or less, expert opinions and guidelines were considered and the search yield was narrowed if the articles met the criteria and applied to the burning question.

\section{Level of Evidence}

The search yielded a total of 245 applicable studies or reviews. One was a systematic review, which is a Level I. Five were a level II; randomized controlled studies. Four studies were cohort studies and rated at a Level III. There was one case-control study rated as a Level IV and one expert opinion rated as a Level VI study. Approximately 3\% of UK people are carriers for MRSA. The NHS planned to reduce MRSA nosocomial infections by $20 \%$ in 2012/2013. The Department of Health prompted mandatory universal screening for elective and trauma surgery at substantial cost and additional resource demand Patients providing to our service with simple upper limb trauma (O’Neill et al., 2014). Appendix A1, Appendix A2 and Appendix A3 show the level of evidence, grades of recommendations and grading of recommendations.

Level of evidence indicates applicability in practice and grade of necessity for implementing programs or pilots. A level I report is indicated for use in practice and a level IV is a mandatory implementation practice. Overall this study found that many of the recommendations could be handled simply by using wipes that kill $S$. aureus and other germs at desks, stretchers, keyboards, medicine carts, etc. 
Table 1. ESBL-E fecal colonization by healthcare contact in the past three months and antibiotic use in the previous month (Young et al., 2014)

\begin{tabular}{llllll}
\hline & Number of participants & Number of participants: & & & \\
Sub-group & : ESBL-E colonized & Not colonized & Prevalence & Odds ratio (95\% C.I.) & $p$-value \\
\hline No healthcare contact or antibiotics & 6 & 95 & $6.30 \%$ & & \\
Primary care & 36 & 452 & $8.00 \%$ & $2.90 *(1.84$ to 4.57$)$ & $<0.0001$ \\
Primary care and antibiotics & 51 & 221 & $23.10 \%$ & & \\
Outpatient & 24 & 245 & $9.80 \%$ & $1.78 *(1.05$ to 3.02$)$ & 0.033 \\
Outpatient and antibiotics & 43 & 247 & $17.40 \%$ & & \\
Hospitalization & 10 & 81 & $12.30 \%$ & $2.38 *(1.08$ to 5.02$)$ & 0.032 \\
Hospitalization and antibiotics & 25 & 85 & $29.40 \%$ & & \\
\hline
\end{tabular}

\section{Grade of Recommendations and Medication Management}

Numerous recommendations were relevant to the advent of early detection and early isolation of MRSA patients. Many researchers suggest that early testing in the emergency room is the best method to prevent the spread of MRSA and the best option to treat. To understand better the recommendations, the recommendations were graded using a Grading Tool (see Appendix A2) that was modified from Dicenso et al. (2004) and the Canadian Task Force on Preventive Health Services. Most of the recommendations were rated as "clear" (see Appendix A3) and several recommendations became "clear" as the studies were rated. Each study supported the early detection and early isolation of MRSA patients to prevent the spread of infection to health care workers and other patients. Emergency rooms are typically point of entry for patients with abscesses and wounds that have become significantly infected. Early detection of an MRSA infection cannot only prevent costly nosocomial infections to other patients but also can prevent health care workers from being colonized themselves. The recommendations by the researchers were unanimous in that cost containment can be made with early identification. These recommendations should take precedence in ERs of current health care settings and protocols should be developed using these as evidencebased guidelines for practice.

One researcher believed that isolation of asymptomatic MRSA patients was costly and inappropriate and did not prevent the spread of Health Care Associated Infections (HAIs). Targeting symptomatic patients such as those who present with open wounds and symptoms of active MRSA infection such as drainage, redness and fever is recommended. Early identification of a patient with active MRSA infection can receive appropriate treatment early, be put on isolation quickly to prevent transmission to other patients and protect health care workers from active infection.

A couple of studies indicated there was not much MRSA flora in the ER setting. One study looked at stethoscopes and the other study looked at environmental surfaces such as desktops, coffee cups, computer keyboards, doorknobs, chairs, etc. (Preidt, 2014). When cultured, no significant growth was indicated on the surface of these items as probably cleaning is sufficient to kill MRSA germs and if ER staff will take the time; this can prevent transmission from patient to patient (Preidt, 2014).

The recommendations will be beneficial to staff in the emergency room only if used or absorbed into practice. Evidence-based practice entails finding supporting literature to answer the burning question and implementing the evidence into practice. If emergency nurses and nurse practitioners will adopt some of the outlined practices, the MRSA infection rate will decrease and the overall MRSA HAIs will decrease as well. Figure 1 shows careful prevention of HCAI-MRSA in the emergency room (Preidt, 2014).

\section{Incorporating Into Emergency Nursing Practice}

Adams and Titler (2010) provide a foundation for promotion of evidence-based practice to improve quality health care in the hospital setting. The toolkit for promoting evidence-base practice included: "(1) selecting a topic for implementation, (2) finding and critiquing the evidence to present, (3) developing an action plan," and (4) trial and error of the plan in the clinical setting. Adams and Titler also prepared an intensive program for preparing advanced practice nurses to promote and disseminate evidence-based practice that included: Interactive work sessions, didactic teaching, consultations with experts and networking to increase peer support. Based on Adams and Titler model, several steps need to occur before early identification and isolation can occur in the emergency room. Preventing the spread of MRSA is vital to the health of staff and patients in any acute care setting. Staff and leaders alike should promote incorporating these studies into protocols and practice policies. Financial data has already shown in some studies (van Rijen and Kluytmans, 2009; Spence et al., 2012) that early detection and isolation can affect the financial cost of the hospital caring for the patient with MRSA. For a health care facility to have a less than adequate point of care testing is primarily costly and a waste of health care dollars. 


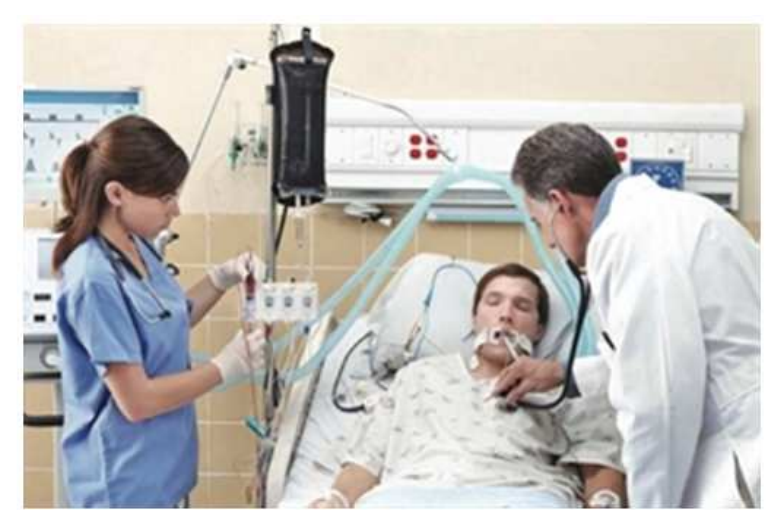

Fig. 1. Practicing oral hygiene on a ventilated patient to prevent HAI-MRSA

The CDC (2011) promotes early detection of MRSA and early treatment. Preventing the spread of MRSA among staff and patients is the priority mark for hospitals caring for MRSA patients. The patient should be cultured on admission to the ER or soon thereafter to establish a benchmark in point of care testing. Waiting longer will prolong treatment with the right medications and could prove costly in terms of other infected patients as staff move from the infected patient's room to clean room, dropping off the infection unintentionally.

Methodist University is willing to implement protocols using evidence-based nursing and will establish early detection and treatment plans for patients who present to the emergency room. About $25 \%$ of patients who present to the ER at Methodist University have wounds in the emergency department. The job of triage and the triage Nurse Practitioner will be to determine what patients fit the criteria for early detection and early isolation.

Isolating an MRSA patient requires certain equipment. To do this properly, appropriate Personal Protective Equipment (PPE) must be worn to reduce the amount of infectious material exposed to the staff. Contact Isolation requires gowns and gloves and masks are optional. Good hand washing is also essential for all staff. Staff must be properly educated about isolation procedures and hand washing as well as disinfecting the surfaces of their stethoscopes and other personal items that may have come into contact with the patient such as scissors.

Methodist University needs to develop a team of specialists to determine the needs of the units and submit the protocols and initiatives for the early identification and isolation. This team should consist of nurses, nurse practitioners in the emergency room, ER physicians, lab technicians, infection control council and administrators. All relevant research must be presented to the team and a discussion of the evidence must ensue. The best evidence, only after considering the feasibility should be implemented. Below is a list of recommendations from the literature that the best evidence is considered:

- Early identification is a cost-saving move

- Early identification and isolation can decrease HAIs and lead to better control of treatment of MRSA infections

- Identification and isolation of MRSA in the emergency is cost-effective and screening all wounds should be employed

- Keeping emergency room surfaces clean prevents the spread of MRSA to other patients and staff members

The purpose of implementing change must be evaluated and re-evaluated. This ongoing process must be a part of the plan developed by Methodist University officials. Ongoing evaluation permits balances in protocols and adjustments. Also if items are being missed, alterations can be made to adjust for that as well. The purpose of initiating the protocol is to reduce the incidence of HAIs in the health care setting. Through early identification and isolation, treatment and precautions are utilized that would hinder or prevent the transmission of the infection to other patients and staff. Staff must receive adequate training on protocols and infection control. Many nurses take infection control for granted. The information must be easily incorporated into a workable education program for physicians, nurses, nurse practitioners, lab technicians and administrators. Questions will continue to arise. The need for nurses knowledgeable in evidence-based nursing is vital.

Barriers to the implementation of protocols and early identification and isolation include cooperation among staff. Some staff may see it as extra work and not want to participate. There will be time constraints for education as shifts differ and some will not want to stay for education on protocols. Overseeing all the staff's education will also be time sensitive. The sheer number of staff that needs to be educated is daunting and can lead to stress. Other preventive measures include the cost of isolation rooms, the cost of point of care testing and the limited resources available.

If the program is successful, other hospitals should look at Methodist University as an example and attempt the same level of care in their own facilities. The outreach of evidence-based medicine is that it encompasses more than one facility. If it is successful, the process should be shared. If others go online with the same program, then the program needs to be continually re-evaluated to determine further room for improvement.

\section{Conclusion}

Based on the burning question, these evidence-based studies provided have indicated that early detection, 
starting in the emergency room and good isolation techniques early at point of entry can prevent the spread of nosocomial MRSA to other staff members and other patients. A cost-saving preventive measure of early rapid testing of all ER patients who present with signs and symptoms and rapid isolation should be implemented without haste. New protocols should be developed following the evidence-based guidelines and ongoing evaluation provided as necessary. Sharing protocols and efforts associated with evidence-based medicine with other facilities is part of the chain of continuing improvement. Supporting evidence should indicate whether or not the protocol should be shared with other hospitals or not. In the end education and reinforcement by the evidence will make the new protocol work.

\section{Acknowledgment}

This study was supported in part by Technology and Healthcare Solutions, Inc. in Mississippi, USA. No conflict of interest to disclose.

\section{Author's Contributions}

All authors equally contributed in this work.

\section{Ethics}

This article is original and contains unpublished material. The corresponding author confirms that all of the other authors have read and approved the manuscript and no ethical issues involved.

\section{References}

Adams, S. and M. Titler, 2010. Building a learning collaborative. Worldviews Evidence-Based Nursing, 7: 165-173.

DOI: 10.1111/j.1741-6787.2009.00170.x

Carman, M.J., J. Phipps, J. Raley, L. Suling and D. Thornlow, 2011. Use of a clinical decision support tool to improve guideline adherence for the treatment of Methicillin-Resistant Staphylococcus aureus: Skin and soft tissue infections. Adv. Emerg. Nurs. J., 33: 252-266. DOI: 10.1097/TME.0b013e31822610d1

CDC, 2011. MRSA statistics. Centers Disease Control.

Creamer, E., A. Dolan, O. Sherlock, T. Thomas and J. Walsh et al., 2010. The effect of rapid screening for Methicillin-Resistant Staphylococcus Aureus (MRSA) on the identification and earlier isolation of MRSA-positive patients. Infect. Control Hospital Epidemiol., 31: 374-381. DOI: 10.1086/651093

Dicenso, A., G. Guyatt and D. Ciliska, 2004. EvidenceBased Nursing: A Guide to Clinical Practice. 1st Edn., McGraw Hill Philadelphia.
Guleri, A., A. Kehoe, J. Hartley, B. Lunt and N. Harper et al., 2011. The costs and benefits of hospital MRSA screening. British J. Healthcare Management, 17: 64-71.

Humphreys, H., H. Grundmann, R. Skov, J.C. Lucet and R. Cauda, 2009. Prevention and control of methicillin-resistant staphylococcus aureus. Clin. Microbiol. Infect., 15: 120-124.

DOI: 10.1111/j.1469-0691.2009.02699.x

Kei, J. and J.R. Richards, 2011. The prevalence of Methicillin-Resistant Staphylococcus aureus on inanimate objects in an urban emergency department. J. Emerg. Med., 41: 124-127. DOI: $10.1016 /$ j.jemermed.2008.08.002

Kuehnert, M.J., D. Kruszon-Moran, H.A. Hill, G. McQuillan and S.K. McAllister et al., 2006. Prevalence of Staphylococcus aureus nasal colonization in the United States, 2001-2002. J. Infect. Dis., 193: 172-179. DOI: 10.1086/499632

Lopez-Alcalde, J., L. Conterno, M. Mateo-Mazón, M. Guevara-Eslava and F. Job-Neto et al., 2009. Gloves, gowns and masks for reducing the transmission of Meticillin-Resistant Staphylococcus Aureus (MRSA) in the hospital setting. Cochrane Library Online Database. DOI: 10.1002/14651858.CD007087

Meyer, E., C. Schröder, P. Gastmeier and C. Geffers, 2014. The reduction of nosocomial MRSA infection in Germany. Deutsches Aerzteblatt Int., 111: 331-336. DOI: $10.3238 /$ arztebl.2014.0331

O'Neill, T., V. Itte and G. Bourke, 2014. MRSA screening in ambulatory upper limb trauma day cases. British J. Healthcare Management, 20: 435-439. DOI: $10.12968 /$ bjhc.2014.20.9.435

Parvez, N., C. Jinadatha, R. Fadar, T.W. Huber and A. Robertson et al., 2010. Universal MRSA nasal surveillance: Characterization of outcomes at a tertiary care center and implications for infection control. Southern Med. J., 103: 1084-1091.

Preidt, R., 2014. Gloves and gowns may reduce MRSA infection in ICUs. AACN Bold Voices, 6: 10-10.

Rohr, U., A. Kaminski, M. Wilhelm, L. Jurzik and S. Gatermann et al., 2009. Colonization of patients and contamination of the patients' environment by MRSA under conditions of single-room isolation. Int. J. Hyg. Environ. Health, 212: 209-215. DOI: 10.1016/j.ijheh.2008.05.003

Shapiro, A.R., S. Raman, M. Johnson and M. Piehl, 2009. Community-acquired MRSA infections in North Carolina children: Prevalence, antibiotic sensitivities and risk factors. N. C. Med. J., 70: 102-107. PMID: 19489364

Sherlock, O., A. Dolan and H. Humphreys, 2010. MRSA screening: Can one swab be used for both culture and rapid testing? An evaluation of chromogenic culture and subsequent Hain GenoQuick PCR amplification/detection. Clin. Microbiol. Infect., 16: 955-959. DOI: 10.1111/j.1469-0691.2009.02948.x 
Spence, M.R., T. Dammel and S. Courser, 2012. Contact precautions for methicillin-resistant staphylococcus aureus: Colonization costly and unnecessary? Am. J. Infect. Control, 40: 535-8.

DOI: 10.1016/j.ajic.2011.07.016

Stenstrom, R., E. Gafstein, M. Romney, J. Fahimi and D. Harris et al., 2009. Prevalence of and risk factors for methicillin-resistant staphylococcus aureus skin and soft tissue infection in a Canadian emergency department. Canadian J. Emerg. Med., 11: 430-438.

Tang, P., A. Worster, J. Sringley and C. Main, 2011. Examination of staphylococcal stethoscope contamination in the emergency department (pilot) study. Canadian J. Emerg. Med., 13: 239-244.

van Rijen, M.M. and J.W. Kluytmans, 2009. Costs and benefits of the MRSA Search and Destroy Policy in a Dutch hospital. Eur. J. Clin. Microbiol. Infect. Dis., 28: 1245-1252. DOI: $10.1007 / \mathrm{s} 10096-009-0775-8$

Young, B.E., D.C. Lye, K. Prabha, S.P. Chan and Y.S. Leo, 2014. A prospective observational study of the prevalence and risk factors for colonization by antibiotic resistant bacteria in patients at admission to hospital in Singapore. BMC Infect. Dis., 14: 1-14. DOI: 10.1186/1471-2334-14-298

Table A1. A Level of evidence (Level I)

\begin{tabular}{|c|c|c|c|c|}
\hline Author \& Year & Title & $\begin{array}{l}\text { Level \& type of } \\
\text { evidence reliability of } \\
\text { studies/guidelines }\end{array}$ & $\begin{array}{l}\text { Results/ } \\
\text { Findings/ } \\
\text { Recommendations }\end{array}$ & $\begin{array}{l}\text { Appraisal of } \\
\text { Evidence }\end{array}$ \\
\hline $\begin{array}{l}\text { Lopez-Alcalde } \\
\text { et al. (2009) }\end{array}$ & $\begin{array}{l}\text { Gloves, gowns and } \\
\text { masks for reducing the } \\
\text { transmission of methicillin } \\
\text {-resistant Staphylococcus } \\
\text { aureus (MRSA) } \\
\text { in the hospital setting }\end{array}$ & $\begin{array}{l}\text { Level I. A systematic review of } \\
\text { randomized controlled studies } \\
\text { were included in this study to } \\
\text { determine the efficacy of PPE } \\
\text { in protecting staff and patients } \\
\text { from acquiring transmitted MRSA }\end{array}$ & $\begin{array}{l}\text { This systematic review revealed that early } \\
\text { identification and early isolation is the key } \\
\text { to preventing the spread of MRSA to other } \\
\text { patients and staff members. When swabbing } \\
\text { for colonized staff members, many were } \\
\text { colonized and could be transmitting via nasal }\end{array}$ & $\begin{array}{l}\text { This study is intended for the } \\
\text { acute care setting. The } \\
\text { importance of this study } \\
\text { is that the literature supports } \\
\text { the of early identification } \\
\text { MRSA }\end{array}$ \\
\hline
\end{tabular}

Table A1. B Level of evidence (Level II)

\begin{tabular}{|c|c|c|c|c|}
\hline Author \& Year & Title & $\begin{array}{l}\text { Level \& Type of } \\
\text { evidence Reliability } \\
\text { of Studies/Guidelines }\end{array}$ & $\begin{array}{l}\text { Results/ } \\
\text { Findings/ } \\
\text { Recommendations }\end{array}$ & $\begin{array}{l}\text { Appraisal of } \\
\text { Evidence }\end{array}$ \\
\hline $\begin{array}{l}\text { Creamer et al. } \\
(2010)\end{array}$ & $\begin{array}{l}\text { The effect of rapid screening } \\
\text { for methicillin-resistant } \\
\text { staphylococcus aureus } \\
\text { (MRSA) on the dentification } \\
\text { i and earlier isolation of } \\
\text { MRSA-positive patients }\end{array}$ & $\begin{array}{l}\text { Level II. A randomize controlled } \\
\text { study of before and after } \\
\text { patients at a } 700 \text {-bed tertiary } \\
\text { care facility. }\end{array}$ & $\begin{array}{l}\text { Rapid screening of the } 489 \text { patients } \\
\text { admitted to the facility during the } \\
\text { study period facilitated priority } \\
\text { isolation and treatment. }\end{array}$ & $\begin{array}{l}\text { These guidelines are } \\
\text { intended for use acute } \\
\text { care setting. The importance } \\
\text { of this study is to initiate } \\
\text { rapid for MRSA screening }\end{array}$ \\
\hline $\begin{array}{l}\text { Van Rijen et al. } \\
\text { (2009) }\end{array}$ & $\begin{array}{l}\text { Costs and benefits of } \\
\text { the MRSA Search and } \\
\text { Destroy Policy at a } \\
\text { Dutch hospital }\end{array}$ & $\begin{array}{l}\text { Level II. A total of } \\
38,943 \text { swabs from a local Dutch } \\
\text { hospital were tested for MRSA } \\
\text { and whether treatment, isolation } \\
\text { at point of contact and resolution } \\
\text { occurred over the course cost of } \\
\text { building isolation of } 2001-2007 \\
\text { in this randomized controlled study }\end{array}$ & $\begin{array}{l}\text { Treatment costs based on swabs collected } \\
\text { from the } 38,943 \text { patients were estimated. } \\
\text { The length of stay, the cost of isolation } \\
\text { (were they properly isolated?) and the } \\
\text { fixed the value of early rooms (PPE, etc.) } \\
\text { were calculated to arrive at figures related } \\
\text { to the mean cost of treating and isolating } \\
\text { a MRSA patient }\end{array}$ & $\begin{array}{l}\text { This study is intended for } \\
\text { the acute care setting. The } \\
\text { importance of this study is } \\
\text { that the cost of isolation is } \\
\text { estimated and the article } \\
\text { demonstrates identification } \\
\text { of MRSA. }\end{array}$ \\
\hline $\begin{array}{l}\text { Kei and Richards } \\
\text { (2011) }\end{array}$ & $\begin{array}{l}\text { The prevalence of } \\
\text { Methicillin-Resistant } \\
\text { Staphylococcus aureus } \\
\text { on inanimate objects in } \\
\text { an urban emergency } \\
\text { department }\end{array}$ & $\begin{array}{l}\text { Level II. A cross- sectional } \\
\text { prevalence study of specific } \\
\text { objects in a large urban } \\
\text { emergency department over } \\
\text { the course of six months. } \\
\text { A total of } 40 \text { specimens } \\
\text { were collected. }\end{array}$ & $\begin{array}{l}\text { This cross sectional study looked at } \\
\text { common objects in the emergency } \\
\text { room and how contaminated these } \\
\text { surfaces become. Of the } 40 \text { samples } \\
\text { received, only one sample was returned } \\
\text { positive; the door knob of the ambulance } \\
\text { door. Commonly touched objects } \\
\text { included computers, desktops, chairs, } \\
\text { wipe boards, etc. The researchers } \\
\text { concluded from the study that routine } \\
\text { cleaning in the emergency department } \\
\text { was sufficient to kill MRSA from surfaces. }\end{array}$ & $\begin{array}{l}\text { This study is } \\
\text { intended for the } \\
\text { acute care setting. } \\
\text { This study was } \\
\text { important in that it } \\
\text { Indicated many } \\
\text { routine surfaces are } \\
\text { not contaminated as } \\
\text { expected. }\end{array}$ \\
\hline $\begin{array}{l}\text { Parvez et al. } \\
(2010)\end{array}$ & $\begin{array}{l}\text { Universal MRSA } \\
\text { nasal surveillance: } \\
\text { Characterization of } \\
\text { outcomes at a tertiary } \\
\text { care center and } \\
\text { implications for } \\
\text { infection control }\end{array}$ & $\begin{array}{l}\text { Level II. This was a retrospective, } \\
\text { observational study of all hospital } \\
\text { admissions over the course of six } \\
\text { months to a large urban hospital. } \\
5375 \text { swabs were done and of those } \\
581 \text { positive carriers were identified. }\end{array}$ & $\begin{array}{l}\text { Patients screened }<48 \mathrm{~h} \text { after admission were } \\
\text { included in the criteria and included patients } \\
\text { from all areas including outpatient and emergency } \\
\text { room. Blood stream infection required a positive } \\
\text { culture. Positive respiratory cultures were required } \\
\text { to diagnose pneumonia. DiversiLab was done } \\
\text { according to manufacturer's instructions. to } \\
\text { manufacturer's instructions. } 158 \text { had clinical } \\
\text { infections and } 73 \text { had clinical MRSA infections. }\end{array}$ & $\begin{array}{l}\text { This study is } \\
\text { intended for acute } \\
\text { care. This study is } \\
\text { important due to its } \\
\text { identification of the } \\
\text { need to do early } \\
\text { identification of MRSA. }\end{array}$ \\
\hline $\begin{array}{l}\text { Guleri et al. } \\
\text { (2011) }\end{array}$ & $\begin{array}{l}\text { The costs and } \\
\text { benefits of hospital } \\
\text { MRSA screening }\end{array}$ & $\begin{array}{l}\text { Level II. A total of } 148,093 \\
\text { swabs over the course of the } \\
\text { first year and } 27,323 \text { swabs } \\
\text { during the second year were } \\
\text { examined for MRSA. }\end{array}$ & $\begin{array}{l}\text { The purpose of the study was to determine if } \\
\text { identification in emergency setting early would } \\
\text { reduce costs associated with Health-care associated } \\
\text { infections (HAI) and if early isolation would } \\
\text { prevent transmission to uninfected patients. } \\
\text { The study concluded that approximately } \$ 282, \\
266 \text { and } \$ 329,117 \text { cost savings in bed days and } \\
\text { isolation costs were saved just by implementing } \\
\text { emergency screenings. }\end{array}$ & $\begin{array}{l}\text { This study is intended } \\
\text { for acute care. This } \\
\text { study is significant } \\
\text { because it examined } \\
\text { the relationship } \\
\text { between HAIs and } \\
\text { emergency room } \\
\text { identification of } \\
\text { MRSA. }\end{array}$ \\
\hline
\end{tabular}




\begin{tabular}{|c|c|c|c|c|}
\hline Author \& Year & Title & $\begin{array}{l}\text { Level \& Type of } \\
\text { evidence Reliability } \\
\text { of Studies/Guidelines }\end{array}$ & $\begin{array}{l}\text { Results/ } \\
\text { Findings/ } \\
\text { Recommendations }\end{array}$ & $\begin{array}{l}\text { Appraisal of } \\
\text { Evidence }\end{array}$ \\
\hline $\begin{array}{l}\text { Sherlock et al. } \\
\text { (2010) }\end{array}$ & $\begin{array}{l}\text { MRSA screening: Can } \\
\text { one swab be used for } \\
\text { both culture and rapid } \\
\text { testing? An evaluation } \\
\text { of chromogenic culture } \\
\text { and subsequent Hain } \\
\text { GenoQuick PCR } \\
\text { amplification/detection }\end{array}$ & $\begin{array}{l}\text { Level III. A series of lab } \\
\text { assays to determine to } \\
\text { effectiveness of the rapid } \\
\text { screening technique for MRSA } \\
\text { was clinically compared using } \\
540 \text { clinical samples. This was } \\
\text { a cohort study. }\end{array}$ & $\begin{array}{l}\text { Researchers utilized rapid assay } \\
\text { saline swabs as clinical controls } \\
\text { and using a GQM assay, tested for } \\
\text { MRSA in swabs from groin and } \\
\text { nasal sites from suspected infected } \\
\text { patients at point of contact. }\end{array}$ & $\begin{array}{l}\text { These guidelines are } \\
\text { intended for use in } \\
\text { the acute care setting. } \\
\text { The importance of this } \\
\text { study was that it can be } \\
\text { utilized to support the } \\
\text { effectiveness of rapid } \\
\text { screening. }\end{array}$ \\
\hline $\begin{array}{l}\text { Rohr et al. } \\
(2009)\end{array}$ & $\begin{array}{l}\text { Colonization of patients } \\
\text { and contamination of the } \\
\text { patients' environment } \\
\text { by MRSA under } \\
\text { single-room isolation }\end{array}$ & $\begin{array}{l}\text { Level III. A series of } 1,100 \text { swabs } \\
\text { were taken from patients and } \\
\text { patients' rooms for identification } \\
\text { of MRSA and contamination of } \\
\text { environmental surfaces with } \\
\text { bacteria. This was a cohort study. }\end{array}$ & $\begin{array}{l}\text { Researchers swabbed both patients } \\
\text { infected with MRSA and various } \\
\text { surfaces in their rooms during a 5- } \\
\text { day course. Sites swabbed included } \\
\text { nose, groin, wounds, abdomen and } \\
\text { ulcers. Room surfaces included tray } \\
\text { tables, lights, side-rails, call-lights, } \\
\text { phones, bedside tables and other }\end{array}$ & $\begin{array}{l}\text { This study is intended } \\
\text { for the acute care } \\
\text { setting. The importance } \\
\text { of this study is that it } \\
\text { concludes that } \\
\text { numerous surfaces } \\
\text { were found clean after } \\
\text { routine cleaning. }\end{array}$ \\
\hline
\end{tabular}

Tang et al. Examination of (2011) staphylococcal stethoscope contamination in the emergency department (pilot) study

Stenstrom et al. Prevalence of and (2009) risk factors for methicillin-resistant staphylococcus aureus skin and soft tissue infection in a Canadian emergency department
Level III. Prospective observation cohort study conducted at there tertiary care centers. There were 100 participants in the study. Swabs were taken of the head of the stethoscope before they were cleaned and a questionnaire on how often the stethoscope was cleaned issued.

Level III. The study consisted of a MRSA SSTI, nested study of 50 cases matched on a calendar date with 100 controls. To quantify the controls, a cohort study was conducted. environmental surfaces. Numerous swabs indicated an active infection on the room surfaces even after the patient's swabs were negative.

Results indicated no significant MRSA infection on any stethoscopes tested. Staff participating in the study reported they did not routinely clean their stethoscopes prior to seeing a new patient. The most commonly reported reason for not cleaning the stethoscope for physicians was forgetfulness while being too busy was the most frequently reported reason for nurses.

Data identified that 2,234 unique patients were infected with MRSA. Infection sites included wounds such as abscess, wound infection not yet identified, carbuncle, skin infection not yet diagnosed, impetigo and cheek infection. A similar San Francisco study isolated 137 or $50 \%$ wound cultures MRSA in with the emergency room.
This study is intended For the acute care setting. This study is significant only because it shows that staff are most likely not carriers of MRSA on their stethoscopes.

This study is intended for the acute care setting. This study is important because it reinforced other literature that the ER early identification was the precedent.

$\underline{\text { Table A1. D Level of Evidence (Level IV) }}$

\begin{tabular}{|c|c|c|c|c|}
\hline $\begin{array}{l}\text { Author \& } \\
\text { Year }\end{array}$ & Title & $\begin{array}{l}\text { Level \& Type } \\
\text { of Evidence Reliability } \\
\text { of Studies/Guidelines }\end{array}$ & $\begin{array}{l}\text { Results/ } \\
\text { Findings/ Recommendations }\end{array}$ & $\begin{array}{l}\text { Appraisal of } \\
\text { Evidence }\end{array}$ \\
\hline $\begin{array}{l}\text { Spence et al. } \\
(2011)\end{array}$ & $\begin{array}{l}\text { Contact precautions for } \\
\text { methicillin-resistant } \\
\text { staphylococcus aureus: } \\
\text { Costly and unnecessary? }\end{array}$ & $\begin{array}{l}\text { Level IV. The researchers used } \\
\text { case-control studies and screened } \\
6,712 \text { patients between the years } \\
\text { January } 2007 \text { and December } 31 \text {, } \\
2010\end{array}$ & $\begin{array}{l}\text { After screening } 6,712 \text { asymptomatic patients } \\
\text { colonized with MRSA, only } 633 \text { were found } \\
\text { to be positive for MRSA infections. } \\
\text { Following these results, the hospital } \\
\text { quit placing asymptomatic MRSA patients } \\
\text { on isolation. The cost of isolation for one } \\
\text { patient was } \$ 8,033 \text { for the first year. }\end{array}$ & $\begin{array}{l}\text { This study is intended } \\
\text { for the acute care } \\
\text { setting. This hospital } \\
\text { quit placing patients } \\
\text { on routine contact } \\
\text { isolations. That makes } \\
\text { this study significant. }\end{array}$ \\
\hline
\end{tabular}

Table A1. E Level of Evidence (Level VI)

\begin{tabular}{llll}
\hline $\begin{array}{l}\text { Author \& } \\
\text { Year }\end{array}$ & Title & $\begin{array}{l}\text { Level \& Type of Evidence } \\
\text { Reliability of Studies/Guidelines }\end{array}$ & $\begin{array}{l}\text { Results/Findings/ } \\
\text { Recommendations }\end{array}$ \\
\hline $\begin{array}{l}\text { Humphreys } \text { et al. } \\
2009\end{array}$ & $\begin{array}{l}\text { Prevention and control } \\
\text { of Methicillin-Resistant } \\
\text { Staphylococcus aureus }\end{array}$ & $\begin{array}{l}\text { Level VI. This article provides } \\
\text { expert advice on the screening } \\
\text { and hygiene necessary to } \\
\text { prevent the spread of MRSA } \\
\text { and to prevent HAIs. }\end{array}$ & $\begin{array}{l}\text { The main concept of this article is } \\
\text { early identification. The researchers } \\
\text { support early emergency admission } \\
\text { identification of MRSA infections. }\end{array}$ \\
& & $\begin{array}{l}\text { The researchers also identified hand } \\
\text { hygiene as the basic method to avoid } \\
\text { intended for the } \\
\text { acute care setting. } \\
\text { This study's main } \\
\text { purpose is to } \\
\text { promote early } \\
\text { identification of } \\
\text { individual to another uninfected individual. }\end{array}$ \\
& & &
\end{tabular}


Appendix A2. Grade of recommendations

\begin{tabular}{ll}
\hline Grade of recommendations & Explanation \\
\hline A & Good evidence to support the recommendation that the condition, or intervention be specifically \\
B & $\begin{array}{l}\text { Fair evidered (clinical encounter, organizational policy, educational practice). } \\
\text { considered (clinical encounter, organizational policy, educational practice). }\end{array}$ \\
C & Insufficient evidence to support the recommendation that the condition or intervention be \\
& specifically considered (clinical encounter, organizational policy, educational practice). \\
D & $\begin{array}{l}\text { Fair evidence to support the recommendation that the condition or intervention be specifically } \\
\text { excluded (clinical encounter, organizational policy, educational practice). }\end{array}$ \\
F & Good evidence to support to support the recommendation that the condition or intervention be \\
& specifically excluded (clinical encounter, organizational policy, educational practice).
\end{tabular}

Appendix A3. Grading of Recommendations

Table A3. a. Grading of Recommendations (A)

\begin{tabular}{|c|c|c|c|c|}
\hline $\begin{array}{l}\text { Author \& } \\
\text { year }\end{array}$ & Title of Article & $\begin{array}{l}\text { Balance } \\
\text { between risk \& } \\
\text { benefit/Grade of } \\
\text { recommendation }\end{array}$ & $\begin{array}{l}\text { Methodological strength } \\
\text { of supporting evidence }\end{array}$ & Implications \\
\hline $\begin{array}{l}\text { Creamer et al. } \\
2010\end{array}$ & $\begin{array}{l}\text { The effect of rapid screening } \\
\text { for methicillin-resistant } \\
\text { staphylococcus aureus (MRSA) } \\
\text { on the identification and earlier } \\
\text { isolation of MRSA-positive } \\
\text { patients }\end{array}$ & $\mathrm{A} /$ Clear & $\begin{array}{l}\text { Recommendations were based } \\
\text { on randomized controlled trials } \\
\text { of a group of } 489 \text { patients. No } \\
\text { significant limitations for } \\
\text { isolating on point of } \\
\text { contact existed. }\end{array}$ & $\begin{array}{l}\text { Strong recommendations from a } \\
\text { literature review perspective. } \\
\text { Implications are that point of care } \\
\text { testing can be used to Implement } \\
\text { rapid isolation and treatment to } \\
\text { prevent exposure and spread of MRSA. }\end{array}$ \\
\hline $\begin{array}{l}\text { Rohr et al. } \\
(2009)\end{array}$ & $\begin{array}{l}\text { Colonization of patients and } \\
\text { contamination of the patients' } \\
\text { environment by MRSA under } \\
\text { single-room isolation }\end{array}$ & A/Clear & $\begin{array}{l}\text { Limitations included the fact } \\
\text { that swabs after a terminal } \\
\text { clean were not done }\end{array}$ & $\begin{array}{l}\text { From a literature review perspective } \\
\text { this is a strong recommendation } \\
\text { because this article reinforces the fact } \\
\text { that MRSA lives on the surface of the } \\
\text { environment and is potentially } \\
\text { hazardous to patients and staff who } \\
\text { might be vulnerable if they do not take } \\
\text { proper isolation precautions. }\end{array}$ \\
\hline $\begin{array}{l}\text { Van Rijen } \\
\text { and Kluytmans } \\
(2009)\end{array}$ & $\begin{array}{l}\text { Costs and benefits of } \\
\text { the MRSA Search and } \\
\text { Destroy Policy at a } \\
\text { Dutch hospital }\end{array}$ & A/Clear & $\begin{array}{l}\text { The limitation on this study is } \\
\text { that it did not take into account } \\
\text { the application to any other } \\
\text { country. However, countries } \\
\text { with high MRSA rates can adopt } \\
\text { and readily apply principles of } \\
\text { early identification and isolation }\end{array}$ & $\begin{array}{l}\text { This article indicates how much early } \\
\text { early identification and early isolation } \\
\text { can save in health care dollars. Not } \\
\text { only does health care spending benefit, } \\
\text { but also patients are at less risk for } \\
\text { bacteremia from acute MRSA sepsis. }\end{array}$ \\
\hline
\end{tabular}

Parvez et al. Universal MRSA nasal:

(2010) surveillance characterization of outcomes at a tertiary care center and implications for infection control

Guleri et al. The costs and benefits of (2011) hospital MRSA screening

Tang et al. (2011)

Examination of staphylococcal stethoscope contamination in the emergency department (pilot) study
A/Clear early identification and isolation as promoted by the authors.

Limitations of the study included the fact only MRSA infected patients were swabbed. This did not decrease the overall rate of hospital-acquired MRSA infections.

A/Clear The limitations of the study included the fact multiple at the same time.

A/Clear

The limitations of the study included the fact that the study was conducted at a time when infection control was at the forefront of everyone's minds Another limitation was that the researchers only tested for MRSA and $S$. aureus. Knowing what other infectious agents were on the stethoscope bells would have been helpful. interventions were introduced

This study is important because it indicates the costly and unnecessary use of contact precautions in cases of asymptomatic MRSA.

There is a strong recommendation from a literature review perspective. This article reinforces the importance of early screening in the emergency room and early isolation and validates the fact that these actions can save money and reduce $\mathrm{HAI}$.

This study is strong from a literature review perspective because it provides support that emergency staff are aware of MRSA and take steps to avoid transfer of infection from one patient to another by cleaning their stethoscopes.

Stenstrom et al. Prevalence of and risk factors A/Clear (2009) for methicillin-resistant staphylococcus aureus skin and soft tissue infection in a Canadian emergency department Limitations included that only

A/Clear $20 \%$ of patients with diagnosis of SSTI were cultured.

This study is strong from a literature review perspective because it is important to identify MRSA infections early on in the emergency room and not delay isolation and treatment. 
Table A3. B Grading of Recommendations (B)

\begin{tabular}{|c|c|c|c|c|c|}
\hline $\begin{array}{l}\text { Author \& } \\
\text { year }\end{array}$ & Title of Article & $\begin{array}{l}\& \text { benefit/Grade } \\
\text { of recommendation }\end{array}$ & $\begin{array}{l}\text { Methodological strength } \\
\text { of supporting evidence }\end{array}$ & \multicolumn{2}{|l|}{ Implications } \\
\hline $\begin{array}{l}\text { Sherlock et al. } \\
\text { (2010) }\end{array}$ & $\begin{array}{l}\text { MRSA screening: can } \\
\text { one swab be used for } \\
\text { both culture and } \\
\text { rapid testing? An evaluation } \\
\text { of chromogenic culture and } \\
\text { subsequent Hain GenoQuick } \\
\text { PCR amplification/detection }\end{array}$ & $\mathrm{B} /$ Clear & $\begin{array}{l}\text { Limitations included the } \\
\text { number of specimens swab } \\
\text { the limited sites swabbed } \\
\text { (only the groin and nose) and } \\
\text { the taking of only one } \\
\text { specimen per site. }\end{array}$ & \multicolumn{2}{|c|}{$\begin{array}{l}\text { Strong recommendations from a literature } \\
\text { review perspective. The article reinforces } \\
\text { the need for early identification of MRSA } \\
\text { to prevent the spread of infection to } \\
\text { others and early isolation. }\end{array}$} \\
\hline $\begin{array}{l}\text { Lopez-Alcalde } \\
\text { et al. (2009) }\end{array}$ & $\begin{array}{l}\text { Gloves, gowns and masks } \\
\text { for reducing the transmission } \\
\text { of methicillin-resistant } \\
\text { Staphylococcus aureus } \\
\text { (MRSA) in the hospital setting }\end{array}$ & B/Clear & $\begin{array}{l}\text { The review did not include any } \\
\text { limitations. Some limitations } \\
\text { could be inferred from reading } \\
\text { the article such as length of } \\
\text { exposure to pathogen and hand } \\
\text { washing techniques, etc. }\end{array}$ & \multicolumn{2}{|c|}{$\begin{array}{l}\text { This article is a moderately strong article } \\
\text { from a literature review perspective. It } \\
\text { does reinforce the need for PPE when } \\
\text { taking care of patients infected with } \\
\text { MRSA. }\end{array}$} \\
\hline \multicolumn{6}{|c|}{ Table A3. C Grading of Recommendations (C) } \\
\hline $\begin{array}{l}\text { Author \& } \\
\text { year }\end{array}$ & Title of Article & $\begin{array}{l}\text { alance between risk } \\
\text { benefit/Grade } \\
\text { recommendation }\end{array}$ & $\begin{array}{l}\text { Methodological strength } \\
\text { of supporting evidence }\end{array}$ & & Implications \\
\hline $\begin{array}{l}\text { Ke and Richards, } \\
\text { (2008) }\end{array}$ & $\begin{array}{l}\text { The prevalence of Methicillin- } \\
\text { Resistant Staphylococcus aureus } \\
\text { on inanimate objects in an } \\
\text { urban emergency department }\end{array}$ & $\begin{array}{l}\text { The } \\
\text { ran } \\
\text { the } \\
\text { shif } \\
\text { on } \\
\text { the } \\
\text { obj } \\
\text { it } \mathrm{x} \\
\text { hav } \\
\text { nun } \\
\text { Mo } \\
\text { not } \\
\text { mis } \\
\text { Am } \\
\text { div }\end{array}$ & \multicolumn{2}{|c|}{$\begin{array}{l}\text { There are limitations to this study. First, swab were s taken at } \\
\text { random times and only on two separate days. Variations in } \\
\text { the cleaning habits of hospital staff working those particular } \\
\text { shifts may have led to different outcomes. Sample acquisition } \\
\text { on different shifts in different months was done to minimize } \\
\text { these effects. However, the exact timing between when an } \\
\text { object was cleaned, when it was used or contacted and when } \\
\text { it was swabbed was not quantified. These timing details may } \\
\text { have had a dramatic effect on the final culture results. The } \\
\text { number of times an object was touched also was not recorded. } \\
\text { Moreover, a convenience sample of only20 ED objects does } \\
\text { not represent the ED as a whole and there may be items that } \\
\text { might have been positive for MRSA but were not sampled. } \\
\text { Among the items chosen for the study, there was a relatively } \\
\text { diverse sampling of ED equipment and patient care areas }\end{array}$} & $\begin{array}{l}\text { This is a moderately strong article } \\
\text { from a literature review } \\
\text { perspective because it presents } \\
\text { evidence that the emergency room } \\
\text { does not seem to be a place where } \\
\text { MRSA thrives. It would be a good } \\
\text { idea to have a sister study to } \\
\text { determine the effects on a unit } \\
\text { within the same hospital to } \\
\text { determine the effectiveness and } \\
\text { reliability of the study. }\end{array}$ \\
\hline
\end{tabular}

